\title{
Nasal septum perforation in patient with pyoderma gangrenosum
}

\section{Perfuração de septo nasal em paciente com pioderma gangrenoso}

\author{
Camilla Bezerra da Cruz Maia', Felippe Felix², Vania Paes ${ }^{3}$, Julia Alves de Azevedo ${ }^{4}$, Eliza Raquel Negrão Grangeiro ${ }^{5}$, \\ Jonatah Lucas N. Riccio', Helen Cruz Rito4.
}

1) Resident Doctor of Otolaryngology.

2) Master for the UFRJ. Doctor of the Department of Otolaryngology of the State Serving Hospital, Health department, Rio de Janeiro.

3) Medical Teacher of the Hospital of the State Server.

4) Resident Doctor (a) of Otolaryngology of the Hospital of the State Server, Health department, Rio de Janeiro.

5) Resident Doctor of Dermatology of the Hospital of the State Server, Health department, Rio de Janeiro.

Institution: Hospital of the Servers of the State of Rio de Janeiro.

Rio de Janeiro / RJ - Brazil.

Mailing address: Camilla Bezerra da Cruz Maia - Sacadura Cabral Street, 178 - Anexo 4 - Saúde - Rio de Janeiro / RJ - Brasil - Zip-code: 20221-903 - E-mail: camillabcruz@yahoo.com.br

Article received in February 3, 2010. Article approved in October 29, 2010.

\section{SUMMARY}

Introduction: The cocaine is obtained from the leaves of the coca (Erythroxylon coca). It can be used in many ways, but the most common is the drug inhalation. The Cocaine also causes vasoconstriction at nasal mucous membrane and its chronic use can cause necrosis and nasal septum perforation. Pyoderma gangrenosum is an uncommon idiopathic disease characterized by ulcerations, usually observed on the legs. Its diagnosis is most common an exclusion of others diseases. So far, there is no specific treatment based on evidence by randomized controlled trials.

Objective: Describe the rare association between Pyoderma gangrenosum and cocaine.

Case Report: E. A., 27-year-old woman with destruction of nasal septum and palate who has been using a big amount of cocaine, been necessary note the difference from which disease cause de damage.

Final Comments: Also there are only three cases of Pyoderma gangrenosum complicated with nasal septum perforation in cocaine users.

Keywords: pyoderma gangrenosum, nasal septum, diagnosis.

\section{RESUMO}

Introdução: A cocaína é extraída das folhas do arbusto da coca (Erythroxylon coca), podendo ser consumida de várias formas, mas o modo mais comum é pela aspiração da droga, sendo absorvida pela mucosa nasal, causando vasoconstricção, levando o seu uso crônico à perfuração de septo nasal. Pioderma gangrenoso é uma doença inflamatória rara, idiopática que se caracteriza pela presença de úlceras destrutivas principalmente em membros inferiores. Seu diagnóstico clínico é muitas vezes de exclusão.

Objetivo: Descrever a raridade de associação entre Pioderma Gangrenoso e cocaína.

Relato de Caso: E. A., 27 anos, com apresentação atípica de Pioderma Gangrenoso com perfurações de septo nasal e palato duro usuária de grande quantidade de cocaína, sendo necessário diferenciar qual patologia causou esse dano.

Comentários Finais: Além da necessidade dessa diferenciação, apenas existem três casos relatados na literatura, envolvendo o Pioderma Gangrenoso complicado com perfuração de septo nasal em usuários de cocaína.

Palavras-chave: Pioderma Gangrenoso; Septo Nasal; Diagnóstico 


\section{INTRODUCTION}

The cocaine it is a extracted alkaloid gives to plant do Erythroxylon gender, Andean and Amazon cultivated shrub command post region. Its dependence possible must to its psychostimulants properties and local anesthetic action. Under the hydrochloride form it is managed by different ways, being able to be inhaled and to be absorbed by the nasal mucous what cause vasoconstriction of nasal arterioles, taking the necrosis and perforation of nasal septum with the drawn out use.

Already the Pyoderma Gangrenosum is a rare, chronic, pertainingdermatosistothespecter of the neutrophildermatosis that is reactive inflammatory processes (1). For being a rare, recognized illness individually only in century XX for BRUNSTING et al. (2), its incidence is difficult to determine, since the published cases are generally isolated or with small number of sick people (3). Generally the injuries are multiple and the skin of the inferior members is the reached place more. In $50 \%$ to $70 \%$ of the patients, associate it a base illness, as intestinal inflammatory illness, rheumatic, hematologic illness or malignancy (3,4). However, the association of Pyoderma with cocaine, as in this in case that physician, were described in only three stories of case in literature.

The case to be related is about a patient with Pyoderma Gangrenosum diagnosised after exclusion of the too much auto-immune illnesses; however its form of presentation atypical and rare must in such a way to the condition of the face how much to the use of cocaine associated with the base pathology.

\section{Case Reports}

E.A., 27 years, feminine sex, mediumbrown, divorced, of the home, natural and coming from Rio de Janeiro, presenting it has 5 years left half-face ulcer that it evolved for inferior members, hard palate and complete destruction of nasal septum. It affirms to be using of great amount of cocaine per 10 years.

In the physical examination, it presented face with edge ulcer badly delimited and erythematosus base with purulent pardon with some epithelized edge areas, occupying, practically, all left half-face. In inferiormembers, injuryulcerated in right leg. Nolonger otolaryngologic examination, there was in the previous rhinoscopy destruction of all nasal septum without areas of inflammatory process and in the oroscopy perforation of hard palate. The otoscopy was normal. It became endoscopy nasal visualizing ample septum perforation, mucous complete without aspect of active infection and presence of residues of mucus (Figures 1 to 6).

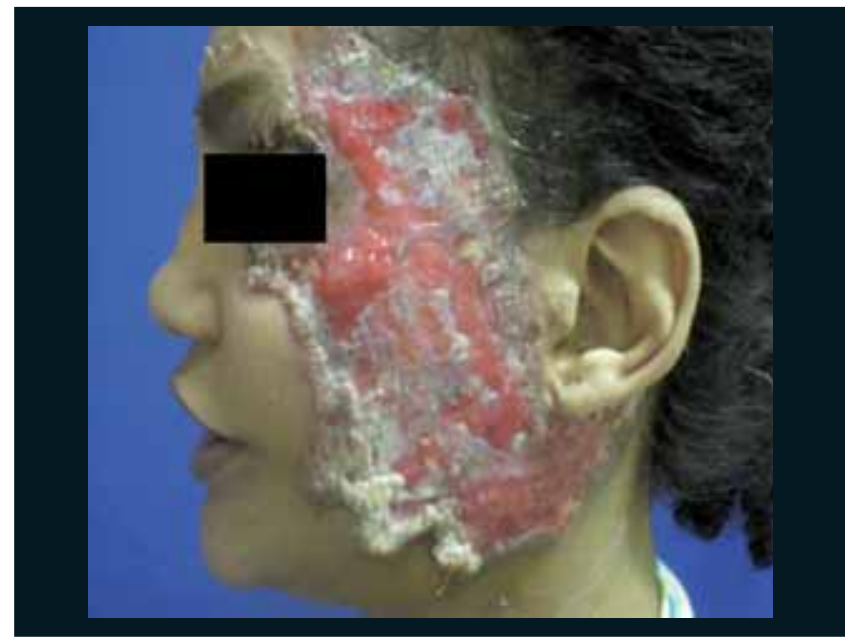

Figure 1. Ulcer of face before the treatment.

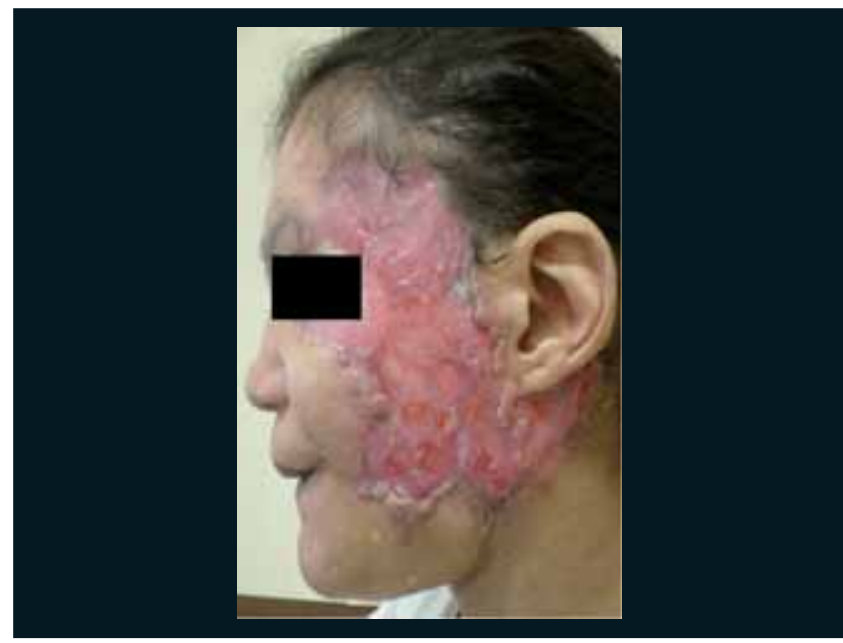

Figure 2. Face ulcer after treatment.

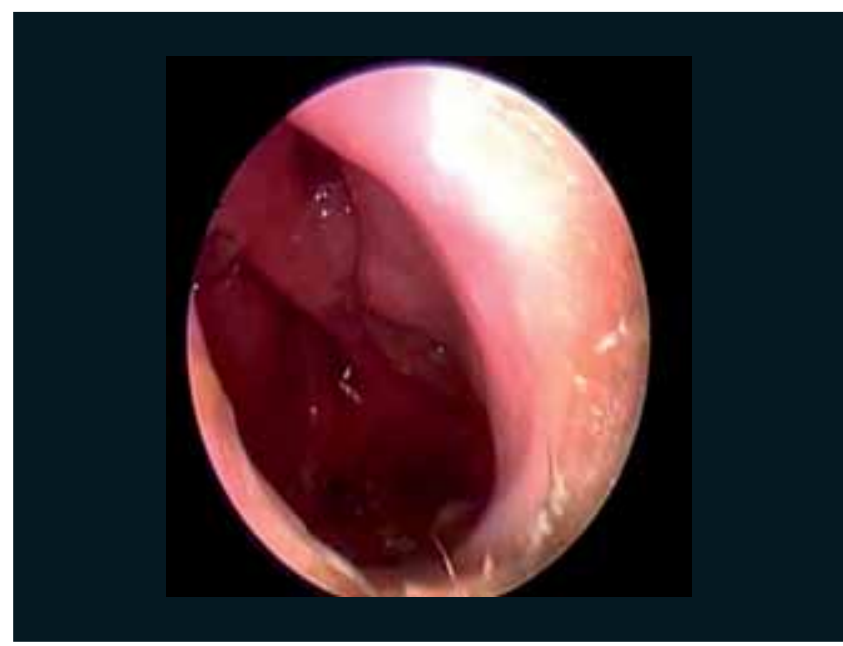

Figure 3. Nasal perforation of septo (1). 


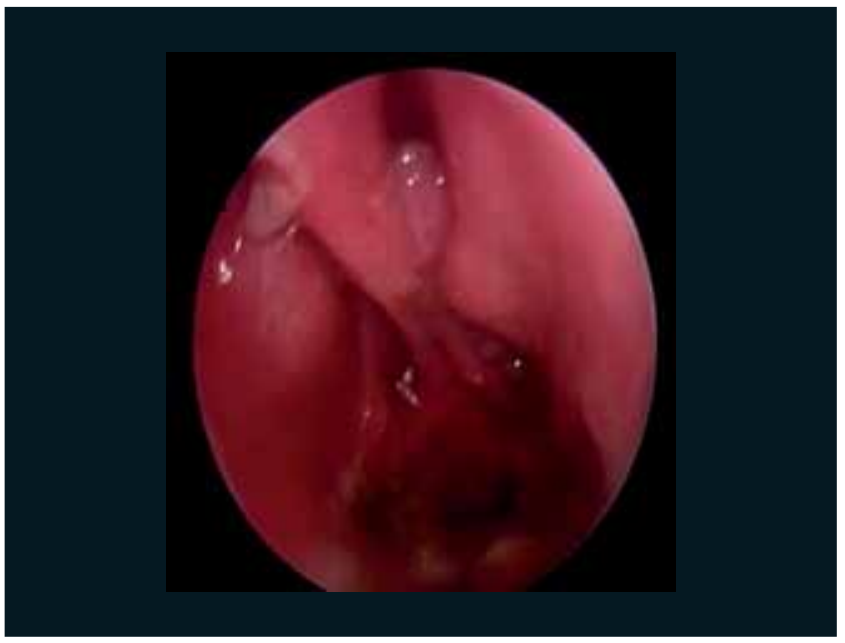

Figure 4. Nasal perforation of septo (2).

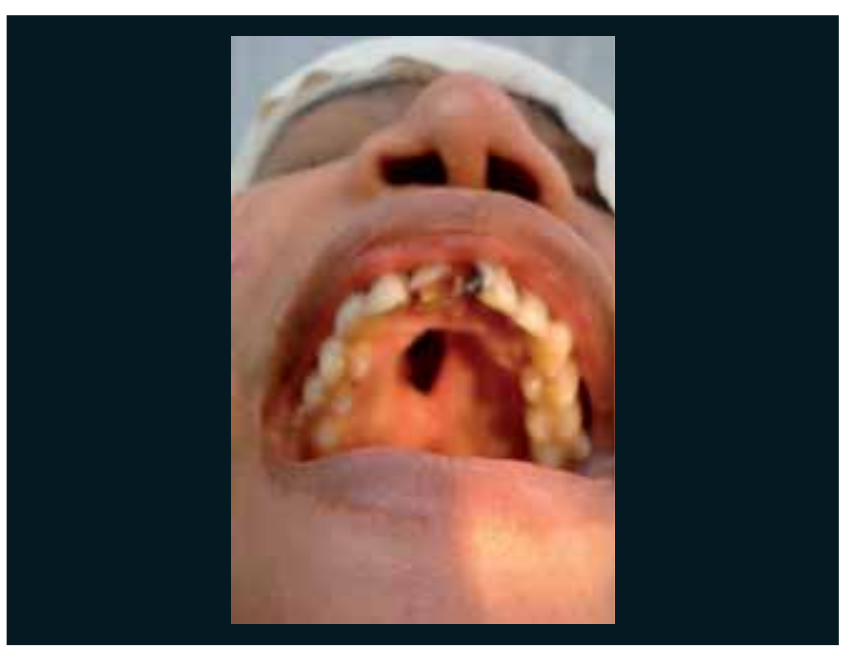

Figure 5. Hard perforation of palate.

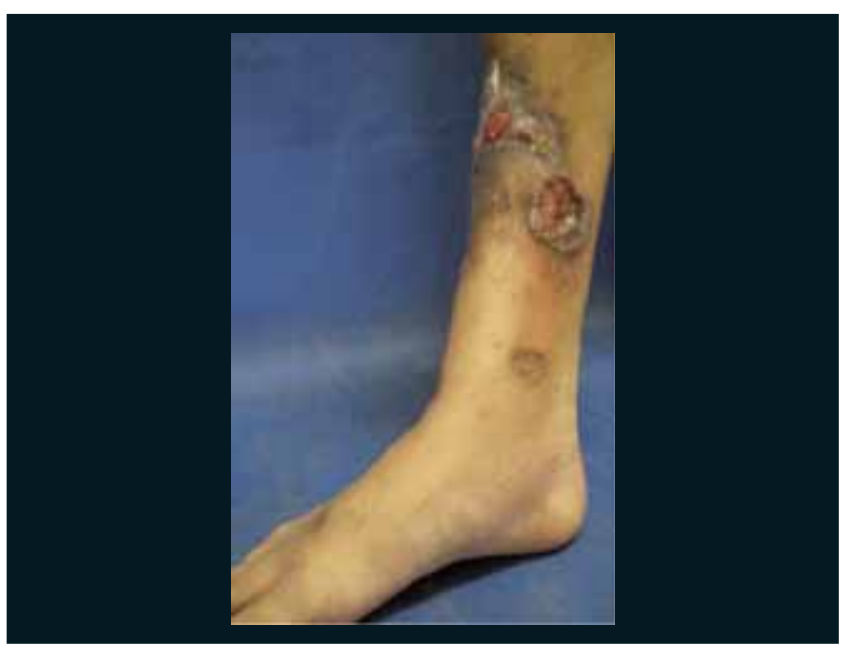

Figure 6. Ulcer of right leg.
In the laboratory examinations, did not evidence systemic illness associate. Anti-HTLV1 and 2 negatives; Ac anti DNA, anti-RNP, C3, C4, FAN, Anti-Ro, Anti-cardiolipin IgM and IgG, PCR and FR inside of the normal values; PPD: $4 \mathrm{~mm}$. Swab of ulcerated injury of skin became, having as resulted S. Aures. Biopsy of skin of the face, being suggestive of Pyoderma Gangrenosum and of fragment of mucous of hard palate: ulcerated chronic inflammatory process with necrosis.

In the treatment, the analgesic use was carried through for pain. Vidisic gel in left eye, since it was without lubrication due to extensive injury. Bandage with silver sulfadiazine in face. Azatioprina 50mg at the day and Prednisona $45 \mathrm{mg}$ at the day. Use of dental prosthesis for occlusion of palatine perforation and transplant of cornea in left eye.

\section{DISCUSSION}

The Pyoderma Gangrenosum is a rare neutrophil illness; of uncertain etiology and that it associates the systemic illnesses in 50\% of the cases as intestinal inflammatory illness, rheumatic, hematologic illness or malignity. It is an inflammatory illness that attacks mainly the skin and is characterized for the presence of painful, destructive ulcers and that they are become enlarged centrifugal, attacking more frequently the inferior members. In this patient, it had the presence of typical injuries (Figure 6) and atypical (Figure 1). The diagnosis of pyoderma gangrenosum is of exclusion, being based on the clinic. The laboratory examinations are non-specific, and, most of the time, only the erythrocyte sedimentation speed is increased. The histopathological examination also is not specific and presents changeable aspects depending on the size of the biopsy and the duration of the illness, but it is basic to exclude other diagnostic (deep mycosis, vascular ulcers, pricked of insects, neoplasias and vasculitis). As in this in case that presented there was an atypical picture with face involvement and previous history of cocaine use in great amount, had necessity to differentiate the illness of base with the use of drugs in the histopathological, what in it helped us in the final diagnosis. Moreover, it has only three described cases in the literature of association between Pyoderma and cocaine considering, thus, greater rarity of the case. One of the reports was in the EWMA, of the Department of Dermatology in Essen in Germany in 2009 on a patient of the using masculine sex of great amount of cocaine it has 10 years and suggesting this fact as cause of the beginning of the Pyoderma. Already to another publication, in 2008, of the Department of Dermatology of the Universitary General Hospital of Valencia in Spain, reports two cases of cocaine users of 30 and 37 years that had also developed the Pyoderma. 
Until the moment, the treatment of pyoderma gangrenosum is controversial and it does not have established and adopted protocols. The options are different antibiotic projects of ample specter, corticosteroids, immunosuppressants and immunemodulatory. It known that the precocious institution of aggressive treatment is capable to diminish pain and to prevent extensive scars. In this in case that, corticosteroids was opted to the use of associated immunosuppressants, getting itself resulted satisfactory with partial healing of the injury of the face, therefore it was sufficiently extensive, and it improves of the general state of the patient. The cares of support as well as local cares are important in the prevention of complications and secondary infections as the use of sulfadiazine of silver. As it had commitment of face and difficulty of ocular occlusion, it resulted in ulcer of cornea and posterior transplant what it got success. In the palatine perforation, prosthesis dental for improvement of the deglutition was made one. Already the septal perforation only becomes fulfilled accompaniment, since the patient persists in the use of inhalable drugs.

\section{CONCLUSION}

The Pyoderma Gangrenosum is a rare inflammatory illness, being necessary to exclude other pathologies for its diagnosis. As it was an atypical case, involving the face, since this illness attacks, generally, inferior members, had necessity to differentiate if the injuries nasal and verbal would be for chemical aggression or the illness of base. Moreover, its association with cocaine is little described, since it only has two cases in literature.

\section{BibliogRAPHICAL REFERENCES}

1. Brunsting La, Goeckermann, O'Leary. Pyoderma (echthyma) gangrenosum: clinical and experimental observations in five cases occurring in adults. Arch Dermatol. 1930, 22:655-680.

2. Benett ML, Jackson JM, Jorizzo JL, Fleischer AB Jr, White WL, Callen JP. Pyoderma gangrenosum: a comparison of typical and atypical forms with an emphasis on time to remission. Case review of 86 patients from 2 institutions. Medicine (Baltimore). 2000, 79(1):37-46.

3. Callen JP, Jackson JM. Pyoderma Gangrenosum: an update. USA: Elsevier; 2007. p 787-802.

4. Costa IMC, Nogueira LSC. Pioderma Gangrenoso e Artrite Reumatóide - Relato de Caso. An Bras Dermatol. 2005 , 80(1):81-2.

5. Hasselmann DO, Bens G, Tilgen W, Reichrath J. Pyoderma gangrenosum: clinical presentation and outcome in 18 cases and review of the literature. J Dtsch Dermatol Ges. 2007, 5:560-564.

6. Reichrath J, Bens G, Bonowitz A, Tilgen W. Treatment recommendations for Pyoderma gangrenosum: An evidence based review of the literature based on more than 350 patients. J Am Acad Dermatol. 2005, 53(2):273-83.

7. SL, Davis MDP. Neutrophilic Dermatoses. In: Bolognia JL, Jorizzo JL, Rapini RP. Dermatology, 2th edition, vol 1. USA: Elsevier; 2008. p. 383-386. 